\title{
The strength of collusion: A conceptual framework for interpreting hybrid social orders
}

\section{Matías Dewey}

Max Planck Institute for the Study of Societies, Germany

\section{Daniel Pedro Míguez}

Instituto de Historia, Geografía y Ciencias Sociales-UNCPBA/CONICET, Argentina

\section{Marcelo Fabián Saín}

Departamento de Ciencias Sociales de la Universidad Nacional de Quilmes, Argentina

\begin{abstract}
By moving away from dualistic perspectives that see social order as the product of strong states but not weak states, this article develops a conceptual framework for interpreting hybrid social orders, i.e. those established by both legal and extra-legal actors. The initial premise is that hybrid forms of social domination resulting from the interaction between legal and extra-legal actors, and regulated by a combination of rational bureaucratic and neo-patrimonial rules, produce relevant economic and political outcomes such as job creation, the supply of basic services and the production of authority. Especially in contexts of continuous economic crisis, ethnic segregation, social marginalization and persistent inequality, these outcomes have ordering effects both in terms of reducing uncertainty and regulating social expectations. Furthermore, in such social contexts, socially tolerated illegal markets play a decisive role. Supported by recent and innovative research, this article concludes with hypotheses intended to promote further research.
\end{abstract}

\section{Keywords \\ Clusters of order, hybrid social order, illegal markets, informality, legitimacy, patrimonialism, social order, state}

\section{Corresponding author:}

Matías Dewey, Max Planck Institute for the Study of Societies, Paulstr. 3, Cologne, 50676, Germany.

Email: dewey@mpifg.de 


\section{Introduction}

Over the past few years, most of the debate on organized crime has been dominated by the discussion of the strengths or weaknesses of what is supposed to be its enemy: the state. Based on a prescriptive perspective that emphasizes what the state should be, a world map has been drawn consisting of countries with strong or weak states. The former are capable of guarding their borders, pursuing criminals and keeping their citizens safe. The latter are dominated by individual interests and are incapable of effectively pursuing criminals because they have co-opted the state. According to this binary point of view, the former are capable of producing order while the latter are not.

Although there is plenty of variation and nuance in this debate, one element remains constant: social order is thought of as the result of a particular relation between state and society in which these entities tend to be treated as mutually exclusive and playing fixed roles in the constitution of order (Scott, 1995). Order is interpreted as being established by the state, whose institutions are incarnations of the universal rational-legal norms, and which has the monopoly on the use of force. In turn, civil society is the recipient of the actions of the state and may contribute to the social order by fostering internal cohesion through its networks and social capital, or subvert the rational order proposed by the state by hosting informal and illegal transactions. Still, from this perspective the state is the main 'producer' of social order, which may be met with the acquiescence or support of civil society, or with resistance or overt challenge by all or some of its members.

Complications arise when there is a synergy between state institutions and actors involved in illegal practices that help both parties to meet certain social demands, or to supply public services more effectively than the rational state can by operating alone. These situations produce alternative, but also accepted, forms of social domination. We call these particular forms of social domination 'clusters of order': a type of social order that produces alternative rules and authorities that deviate from rational legal norms, but are still accepted by civil society (or at least parts of it). These forms of domination are usually based in particularistic norms and interpersonal ties, and include only a restricted nucleus of social actors. Different from forms of domination based on larger social consensus and universal norms, these forms usually involve greater levels of coercion and extortion among actors with competing interests. However, while these social orders do not optimize the levels of cooperation, their performance surpasses that of the formal and legal institutions of the state when these cannot supply basic social needs or achieve basic forms of authority and legitimacy. A mutual adjustment of social expectations and social relations organized by an accepted set of rules and norms allow us to speak about social order.

Our aim in this article is to develop the notion of clusters of order as a conceptual framework that will help understand these hybrid forms of social domination. In this way, we aim to make a contribution to the literature on the production of social order - in particular in regard to the role played by the state and informal rules - by combining three perspectives on social order that are usually perceived as mutually exclusive. An initial series of studies highlights the bottom-up forces that produce social cohesion. In this body of literature, the state remains as an external, independent actor (Fligstein and 
MacAdam, 2012: 173; North et al., 2009), while autonomous actors interact in the context of networks (Granovetter, 1985) and strengthen ties of trust, which produce social order (Gambetta, 1988). A second body of research highlights the role of the state intervening in society and fostering cooperation and coordination among actors by promoting trust in authority and building up solid institutional arrangements (Fligstein, 2001; Levi and Stoker, 2000; Swedberg, 2002), indirectly stimulating cooperation among actors (Erikson and Parent, 2007) or generating new patterns of interrelation between formal and informal norms (Nee, 1998: 86). A third body of literature focuses on weak institutions, which are not capable of effectively enforcing the law and might thus lead to the rise of mafia-type groups (Gambetta, 1993; Varese, 2004; Volkov, 2002). We believe that current social developments render each of these perspectives incomplete. We will show that the manipulation of the rule of law in terms of selectively justifying or enforcing its imposition and bargaining legality are all practices in which state authorities and economic actors interact in informal settings.

Our argument will be illustrated by three cases published in this special subsection of the journal. We have selected cases in areas affected by the 'Third Wave' of democratizations that took place in Eastern Europe, Africa and Latin America during the 1980s and 1990s. These were also areas in which neoliberal policies and the effects of globalization were particularly relevant, such as the delegation of the traditional functions of the state to the private market (healthcare, education, pension programs, etc.), the growth in labor flexibility and instability, or the increase in personal insecurity. As we will see, these effects of neoliberalism and globalization, plus the transformation of the political system that took place in these areas, created latitude for clusters of order to develop. However, our argument does not present a historical perspective in which 'clusters of order' are seen as a new or recent phenomenon. A brief look back through history reveals that what we call clusters of order existed long before the present day.

For example, a substantial body of literature shows that in Europe from the Middle Ages until the mid-19th century, the various states' capacity and autonomy depended strongly on practices such as piracy, privateering and mercenarism promoted by the states themselves (Gathmann and Hillmann, 2014: 2; Thomson, 1992, 1994). In the Ottoman Empire too, social order during the process of state-making was based on cooptation and bargaining with bandits/mercenary troops (Barkey, 1994: 8). Meanwhile, recent cases of regime transition such as those included in the following section also exhibit social orders sponsored by alliances between states and extra-legal actors. Kupatadze (2012: 192), for instance, shows this in the transitions to democracy in Ukraine, Kyrgyzstan and Georgia. Similarly, in post-socialist Russia, Varese (2004) reveals the complex relationships between state agencies lacking enforcement capacity and emerging mafia groups offering protection. Such connections, as Vadim Volkov recently asserted, explain the consolidation and strengthening of the Russian state from the year 2000 onwards (2014: 172).

However, while this handful of examples show that the phenomenon we identify as a hybrid social order is not new, our observations and the case studies presented indicate that combinations of formal and informal sets of rules gained a new momentum when three interrelated conditions developed. The first of these is the introduction of neoliberal policies as a development strategy that has reconfigured worldwide economic and social 
relationships (Connell and Dados, 2014). Examples include the emergence of extra-legal powers in charge of enforcing property rights; the effects of new transport technologies that give new impulse to transnational markets and reshape local economies; or the disciplinary force applied to 'low-paid and insecure workforces needed by comparativeadvantage strategies' (2014: 129). Second is the massive growth of government regulation of the economy and social relationships, which 'created niches for organized criminality' (Cribb, 2009: 6) because it fostered the expansion of illegal markets for goods that were the object of social acceptance in spite of prohibitions (Beckert and Dewey, 2017). Third is the rise of what Loïc Wacquant (1996) defines as 'advanced marginality' produced by the breakdown of the productive apparatus along with market segmentation, which led to a 'dense system of informal networks' and extended clandestine economic activities (Weiss, 1987). We argue that the superposition of these three phenomena provoked more complex relationships between formal and informal sets of rules, giving rise to what we observe as clustered social order.

The next section begins with a conceptual clarification of the notion of 'clusters of order', locating it within the available literature. We discuss these forms of social domination as resulting from a combination of two forms of social organization, bureaucratic and patrimonial, that have usually been perceived as mutually exclusive. Along with reference to extant research on informal institutions (Helmke and Levitsky, 2006: 12-13; Lauth, 2000; O'Donnell, 1993), we allude to the cases presented later in the section, which illustrate these forms of order not only coexisting, but appearing to reinforce one another. The third section of the article refers to the synergies that occur between the 'problem-solving' character of the clusters, and the construction of authority and subsequent social domination that takes place in these social spaces. We conclude the article by offering three hypotheses derived from our framework and the case studies that provide grounds for further and more detailed comparison.

\section{The hybrid nature of clusters of order}

The word 'cluster' is used in several disciplines, such as sociology and political economy, to designate highly specialized units producing goods, services or knowledge. As icons of efficiency and innovation, these islands appear as successful formats of economic cooperation throughout the world. Hence, clusters are proposed as producers of nodes of a certain order, as exemplary forms of economic governance, even in contexts of dramatic impoverishment and economic restructuring (Becattini, 2004; Porter, 2008).

Along with the development of these 'virtuous' clusters, understood as a result of globalization and technological change, we intend to show the development of hybrid clusters in which there is a synergy between legal and illegal actors. In general terms, this type of cluster develops in territories in which the rational institutions of the state are not able to guarantee the meeting of basic social needs or to exert lawful and effective control over the use of force, and also fail in securing society's compliance with legally sanctioned norms - two main features that, according to Max Weber (1956), define domination (Herrschaft). However, we argue that a characterization emphasizing the 'weak' or 'absent' character of these states limits our understanding of the situation. Although we observe that clusters of order emerge in spaces in which the state's formal means of 
social domination are severely contested, we also find that the state is nevertheless informally and/or illegally present. Therefore, the provision of goods and services in such areas takes place as the result of the interaction between legal and extra-legal actors, leading to a regime of domination in which patrimonialistic and rational bureaucratic principles are closely intertwined.

By recognizing formal and informal norms as well as the specific ways in which they are enforced, our approach exhibits clear connections with research on neo-patrimonial forms of domination and explores links between such forms and actors in illegal markets (Bayart et al., 1999; Charrad and Adams, 2015; Erdmann and Engel, 2007; Hibou, 2004; Lauth, 2000; Reno, 1995; Zabludovsky Kuper, 2011, 2016). Illegal economies that provide informal jobs and the means to sustain daily life to large groups of people are not isolated and usually involve state actors acting 'off the books'. In this sense, we could say that contested domination of the rational institutions of the state does not mean the total absence of some form of domination or the inexistence of authority. Alliances between legal and extra-legal actors, private companies and public agencies, or local and foreign actors are governed by two different sets of rules - formal and informal - that permeate each other, and this interdependence is precisely the condition for the generation of relevant economic resources, authority and social order.

In this regard, Erdmann and Engel's definition of neo-patrimonial rule is instructive: 'a mixture of two co-existing, partly interwoven, types of domination: namely, patrimonial and legal-rational bureaucratic domination' (2007: 105). In the studied clusters, patrimonial forms of domination prevail, thus relations between rulers and ruled are not based in impersonal social norms or laws, but on interpersonal ties and alliances. In this context, formal laws and bureaucratic and rational administrative principles exist and are acknowledged, although in practice they are not always observed. What is crucial is that legal-rational rules in the context of particularistic power relationships create new possibilities for action and, more importantly, additional room for selective enforcement of the law. This last element is of great importance: just as in legal markets, the internal coordination of illegal markets needs instances of norm enforcement, a task that may be performed informally by state actors, especially when the traded commodities are socially accepted and the workings of the market produce positive externalities (Beckert and Dewey, 2017; Dewey, 2016). In this context, different types of actors have 'a certain degree of choice as to which logic they want to employ to achieve their goals and best realize their interests' (Erdmann and Engel, 2007: 105). It follows, then, that the cultural layers on which authority and domination are constructed within a cluster of order are of an ambiguous character. The actors that participate in such clusters are not necessarily inclined in favor of one form of domination or the other (rational or patrimonial). Instead, they may combine such principles according to circumstantial conditions.

Clusters of order usually develop in contexts with strong socio-economic inequalities, spatial segregation and the influential presence of informal and illegal markets. Further to what is revealed by neo-patrimonial approaches regarding how clusters emerge from the combination of rational and particularistic rules and social ties, an additional feature that helps us to understand why clusters of order develop in these contexts is the fact that they are able to create certainty where lives are threatened by high levels of contingency. 
The previously mentioned phenomena associated with globalization and neoliberal policies (i.e. the delegation of traditional state functions such as healthcare, education, etc. to the private market; the growth in labor flexibility and instability; the increase in personal insecurity) threaten vital dimensions of life. It is here, then, that instances enabling a restructuring of expectations and social bonds become relevant. Analyzing social order from a perspective that focuses on the ways actors manage everyday uncertainties allows us to consider the mechanisms that reduce uncertainty as sources of social order. Accordingly, the forms that allow actors to handle uncertainty become contingent ways of ordering interactions and expectations. The case studies put forward in the following subsection show that the order within clusters emerges due to the continuous resolution of recurrent problems: supply of basic services, recognition, mobility, personal security and enforcement of norms.

These problems refer directly to uncertainties and consequently to demands whose resolution is subject to permanent dispute and negotiation between state and non-state actors. The outcome of this process, if successful, is the reconstitution or production of normative expectations (Luhmann, 1983: 64) along with their instances of enforcement, which tend to provide basic forms of certainty. Thus, the internal dynamic of clusters of order corresponds to two current observations. On the one hand, these formats of domination are accompanied by the development of rules of conduct, ways of penalizing transgressions, codes of behavior, and norms subject to continuous negotiation in particularly unprotected populations (Clunan and Trinkunas, 2010; Nordstrom, 2000: 46). On the other hand, as Diane Davis expresses, networks of state and non-state actors support social relations whose primary objectives are maintaining exchange networks, securing markets and economic survival, and which provide stability and certaintyalbeit through informal means - to people's lives (Davis, 2010). In sum, we may conclude that the clusters of order proposed here are configured by the combination of rational and patrimonialistic rules and institutions, and develop in particular contexts. These contexts are characterized by scant access to resources and the fact that the informal imposition of rules and the construction of additional informal forms of authority and social domination are able to provide certainty to a significant portion of civil society. It is possible that these clusters do not provide certainty for all members of society; clusters of order in which the illegal component is particularly relevant are especially liable to create uncertainty for those who do not participate in them. However, it does provide certain feelings of security for those who are involved in those clusters, which are usually those who are unable to find similar resources in the institutions that should supposedly provide more universal forms of social order.

\section{Contexts and cases}

The cases we present in this subsection tend to confirm that clusters of order emerge when the synergies between state agents and institutions and actors involved in illegal activities result in arrangements that deliver relevant economic outputs, the construction of authority and, with it, social domination. The fact that these synergies enable state agents and illegal actors to provide relevant assets such as jobs, valued merchandise and particular forms of certainty leads to members of civil society acquiescing to, or even 
accepting, the new situation, even when order in these clusters is achieved using significant levels of coercion. This process creates a certain form of authority and domination, although this is less stable than when concrete social orders resemble more neatly rational forms of domination.

The case presented by Arias and Barnes (see this special subsection) illustrates this quite clearly. The authors show that Rio de Janeiro 'favelas' (shantytowns with urban structures that distinguish them from the rest of the city) have long maintained internal forms of social organization and autonomous security systems that bolster internal cohesion by managing neighborly disagreements and suppressing conflict. The specific actors that produce these forms of order have varied over time, are different in different areas of the city (drug gangs in the southern and northern areas of Rio, and vigilante groups called militias in the west area) and show nuances in the levels of violence they exert and types of crimes in which they are involved. Gangs tend to use more violence and are involved in drugs; militias use less violence and are not involved in overt illegal activities. However, both forms of criminal organizations, while having quasi-dictatorial powers and using significant levels of coercion, generally require a modicum of legitimacy and at least the tacit consent of the community.

To gain such legitimacy, both forms of criminal organizations establish an exchange expectation with residents. Usually, residents respond to militia and drug gangs' expectations to maintain silence in front of official authorities and tolerate some degree of police abuse that stems from efforts to repress the gangs' criminal activities. In exchange, residents expect them to provide basic security against various types of physical violence (i.e. rape, robbery, burglary, etc.). In addition, some of the poorer residents look toward these groups for basic social assistance, which is particularly common in situations in which criminals have established familial or pseudo-familial ties. Residents also expect these groups to support social activities and collective action, for example by mediating in relations between the community and the state, to speak out against police abuses, and aid in bringing larger programs and services to the communities in which they operate by building relationships with politicians and state bureaucrats.

The case of Mozambique presented by Hübschle (in this special subsection) suggests similar dynamics in one point, but nuances in others. The article analyzes issues associated with the hunting or 'poaching' of rhinos and the trafficking of rhino horns in national parks. At the same time, political and economic matters are bound to these illegal activities. On the one hand, given the long history of exclusion of the original African population by white administrators, rhino poaching is valued by many excluded Africans as an act of political rebellion. For these people, rhino conservation and protection are closely linked to colonial land appropriation, subjugation, exploitation and loss of hunting rights for local communities. This perception is exacerbated by the high number of deaths of poaching suspects in restricted areas by special task groups and security forces. Thus, the prevalent sentiment among many locals is one of wild animals being valued higher than black lives; a sentiment that helps legitimate those involved in the illegal economy of horn trafficking.

In addition to channeling sentiments of political rebellion, rhino poaching also has an inherent economic logic. Unlike the slow trickledown of economic resources for the less well-off delivered by the social relief policies of the state in and around conservation 
areas, community members observe the upward social mobility of kingpins, poachers and their families. They receive partial benefit from the influx of hard cash that comes from these activities. For example, kingpins may offer a 'village party' by slaughtering a few cows and providing traditional beer upon the return of a successful poaching expedition to the Kruger National Park. They may also construct servitudes and water wells, and occasionally donate a number of cows for slaughter for the benefit of the community. Thus, poachers and traffickers are perceived as a type of social bandit in the mold of Robin Hood, which explains their degrees of legitimacy in the context of village communities. In addition, given the high profit present in poaching activity and the comparatively low wages earned by state agents, the latter often overlook poaching activity or assist hunters with operational intelligence, especially when relatives are involved in hunting crews. Furthermore, it is also commonplace - and not really surprising - for rangers, field scouts and other park staff to start their own hunting crews or become involved in poaching to supplement their meager earnings.

On the other hand, however, deep rifts exist within village communities about poaching activities. Women especially have misgivings, since the frequent murder of suspected poachers and traffickers by security forces and task groups raises fears for children and husbands and the potential loss of breadwinners should they be killed or arrested. Thus, far from being supportive of poaching, some community members are concerned that poaching has affected the social fabric of village life, mostly to the detriment of women and children. This leads to the observation that, although the political symbolism of illegal activity has a greater weight in this case than in the Brazilian case, common traits are still present. Clusters of order are again revealed to emerge when the synergies between illegal actors and state agents are able to produce an order that delivers more relevant resources to a certain sector of the population than 'rational' public institutions can afford or are able to provide. It is clear that there is a cost involved, and that certain social sectors pay a higher price for this type of arrangement, but it also becomes evident that certain forms of authority and legitimate domination are constructed in this process.

Finally, Stephenson's study of illegal activity in Russia since the fall of the Soviet state also shows clusters of order that result from the synergy of state agents and illegal entrepreneurs, revealing in this case, however, an important cleavage in the process. The market reforms of the 1990s were made in the context of lawlessness and chaos. As the stable structures of social order collapsed, street gangs and organized criminals, as well as former and serving police and security officers, formed predatory networks that used force to demand tribute from business people and ordinary citizens, while all over Russia battles raged for appropriation of state property, with both illegal and legal entrepreneurs using violence and coercion in the capture of assets. This phase of greater violence mutated toward the end of the 1990s and the beginning of the 2000s, when the state was credited with restoring order and re-establishing a monopoly on the legitimate use of violence. The contrast between these two phases is also present in the way that legitimacy and authority of the illegal and legal allegiances of actors that ruled in these spaces was achieved.

In the context of weak law enforcement and the collapse of the state in the early 1990s, some of the larger criminal organizations turned into a sort of proto-state, combining the simultaneous protection and extortion of local businesses with the provision 
of limited welfare to residents, such as assisting poor residents with money and free vegetables or protecting them from non-gang-related crime. At the same time as providing these basic resources, their power in these areas of the city was absolute given their capacity to control police access to them, intimidating and even killing those officers who tried to fight against them, and bribing those who did not.

Interestingly, this form of dominance changed by the end of the 1990s when statebased power networks had been considerably strengthened. The prosecutions of many of the leaders of criminal groups also contributed to undermine their power structures and seriously disrupt their activities, though without completely disintegrating their territorial power structures. This forced the leaders that traditionally operated with ruthlessness to become astute political operators, building lasting alliances with the state-based networks of power.

Instead of violence, in this new context criminal organizations used the exchange of money for administrative resources as a way to advance their interests. For example, they used their legally owned or controlled companies to transfer funds to police departments, State Prosecution and the Department for the Struggle against Organized Crime (UBOP) for office equipment, building renovations or new transport. In return they got significant protection. Also, they took care to build greater social consensus through charitable activities and the sponsorship of events and projects organized by local authorities, such as helping veterans, children and pensioners, or building a sports center or other building for the communal use of all residents in their area.

In sum, the three cases we present show, with some variation, that clusters of order emerge when the synergies between actors involved in illegal activities and state agents are able to deliver important resources to certain sectors of the population and achieve a certain degree of authority and domination in these groups. These forms of domination usually involve greater levels of coercion and lower levels of cooperation than those based on rational and universal institutions. However, in the contexts in which they actually develop they are more efficient than the concrete manifestations of the rational state that are present in that moment in time. In this sense, they show greater productivity than the rational institutions of the state in terms of simultaneously delivering material goods (jobs, social assistance, etc.) and creating authority and social order. It is important to note that the levels of coercion and legitimacy vary between different kinds of clusters. Thus, in the case of Rio de Janeiro, militias seem to use less coercion and have a higher degree of consensus than drug-related gangs. In Russia, the forms of organized crime that developed in the late 1990s tend to use less coercion and involve more legitimacy than had previous groups earlier in the decade.

\section{Discussion: Producing resources, reducing uncertainty and configuring social domination}

We may summarize the previous characterization of clusters of order by pointing out that from a bottom-up perspective, the order in clusters can initially be explained as emerging from socially constructed solutions to problems that should, in conventional social theory, be solved by the 'rational state', such as public security, transport, communication or the provision of formal employment. From this perspective, the fact that this articulation of 
social actors delivers critical resources and certainty promotes the acceptance or tolerance of the liabilities that are often associated with illegal activities and social actors. Additionally, the tolerance or acceptance of informal or illegal activities is subject to continuous change, either because some are legalized or because social values change. Either way, social acceptance provides the state, criminal organizations and other actors of civil society with incentives to engage in illegal activity. Once a certain level of tolerance or acceptance is present, illegal actors have more room for innovation at their disposal and clusters of order may change or even dissolve according to different circumstances.

From a top-down perspective, power-holders channel demands according to the wide range of legal and illegal possibilities. Drugs, people, weapons, protection, public security, DVDs, CDs, perfumes, fake clothing, (exotic) animals, stolen goods, transport, fake medicines, auto parts, vehicles, communications and various smuggled goods represent markets in which legal and illegal actors take part and form extremely complex networks. Although a priori the legitimacy of illicit activities is not connected to any one sector of society, it is especially prevalent in social contexts exposed to processes such as labor informalization, spatial segregation and rapid urbanization. In fact, under these conditions the use of legal, informal and illegal means allows state agencies and non-state actors to meet demands. In other words, the existence of socially accepted informal and illegal activities offers those actors additional possibilities to produce profit and order, or at least a type of order that yields significant profit for those in the commanding positions.

In sum, the notion of clusters of order highlights the existence of areas in which the combination of legality and illegality, and the transformation of authority and its wider social acceptance leads to the emergence of order. The emergence of this form of order is provoked by the convergence of the interests of state agents, civil institutions, private companies and criminal organizations. From an economic point of view, this state/criminal/civil joint venture promotes the expansion of informal and illegal economies that generate employment and sociability networks. From a political point view, the role of informal politics gains importance as a regulatory frame between the legal and illegal worlds. In this context, police organizations, political parties and civil institutions stand out for their ability to extend enforcement to the informal and the illegal.

Though the active role performed by the state - especially the police, the military and political parties - is emphasized in the notion of clusters of order, this does not mean adopting a state-centric perspective. Instead, the notion helps to shed light on a phenomenon that is usually ignored in other approaches, such as those emphasizing the dichotomy of weak/strong states. This is a phenomenon frequently noticeable in Latin American cities and in some countries in Eastern Europe and Africa: that states make alliances with illegal actors in order to maintain control over territories, or maintain economic and social order. Seen in the context of structural transformations that generate uncertainty, hybrid orders emerge as a result of capitalizing on the uncertainty related to the labor market, access to certain goods and the weakening of the state in terms of the regulation of norms and legal presence. However, although the cases presented above reveal that the emergence of clusters of order result from these basic conditions and share some common features, we have also stressed certain variations between each one. In the concluding section, we turn back to continuities and contrasts in order to propose several hypotheses regarding the origins and characteristics of these clusters of order. 


\section{Concluding hypotheses}

In our view, clusters of order emerge when the synergies between state agents and actors involved in illegal or informal activities lead to the development of material resources and present opportunities to members of civil society that provide them with a certain degree of authority, or are at least presented in a way that leads to society tolerating the illegal activities. It is not that there is an absence of tension or conflict within these clusters, but that the outcomes they deliver and the basic levels of certainty they provide lead to substantial parts of civil society accepting their authority and the activity that takes place within them. Thus, actors are able to construct alternative forms of domination, at least in certain territories or in a certain social locus.

In this sense, clusters of order always imply the production of some form of social domination that regulates social interaction and provides basic resources to a certain sector of the population. This is why we cannot speak of weak or strong states, but rather it would be more appropriate to understand that what is produced in such clusters is a particular form of state. Seen from a classic Weberian perspective - prominent in studies of organized crime - these forms of state may be seen as weak, but if we part from this rather biased view we may recognize that these processes lead to the constitution of different forms of state. In fact, as we mentioned before, our observations regarding clusters of order show affinity with research on current forms of the neo-patrimonial state as well as with studies on the role of illegal economies in the 'continuous process of state formation' (Bayart et al., 1999; Hibou, 2004). However, as with all forms of domination, it is important to note that the particular form constituted in clusters of order is also disputed and transformed, and thus has its own variation and history. To say that clusters of order contain forms of accepted authority and social domination is not to say that these are constant and undisputed. What we are trying to postulate here is that these forms of state cannot be understood from a teleological perspective, that they cannot be considered as a deviation from the rational state or an archaic form of public institution that will eventually reach such a stage.

Another important element is that, while we do not think it is epistemologically acceptable to understand these forms of state as mere deviations from a theoretical model, the model of the rational state is part of the local culture of at least some of the civil societies explored in the cases studies. Thus, as current research shows (Arias, 2006; Auyero and Berti, 2015; Dewey, 2012, 2015; Rodgers, 2006), the same clusters of order in which alternative forms of domination are constituted also contain elements of the rational state present in the formal rules, and some of the expectations, of at least some sectors of civil society. This leads us to our first hypothesis: Clusters of order emerge as the result of interaction between two sets of actors. On the one side, there are the institutions proper of the rational state, which are inherent to the formal design of official institutions and the expectations of social actors. On the other side, informal institutions govern political and economic relations. As well as providing certainty and different types of resources to social actors, this synergy between formal and informal institutions also confers unlawful actors a certain degree of authority.

A second associated hypothesis refers to the previously mentioned observation that clusters of order are not free of internal tensions and are in fact the result of a history of 
different types of events. As in all forms of social order, clusters emerge from synergies between quite different institutional models and cultural demands. Order in clusters results from a certain equilibrium and compromise between these models and demands, the constant tension between which is manifested in the frequent need to employ coercion to sustain such order and in the unstable character of authority and legitimacy in those orders. Given their unstable character, these synergies may eventually turn into entropies when the liabilities associated with upholding the order make them unsustainable, or when alternative orders are seen as more convenient. Therefore, according to our hypothesis clusters of order are unstable and change over time due to inherent tensions.

A third hypothesis to an extent provides more relevance to the second by referring to the way a certain cluster of order is configured and that its stability is contingent. The case presented by Stephenson is quite eloquent in this respect, as is that presented by Arias and Barnes. As shown in their study, clusters of order differ significantly in different regions of Rio de Janeiro, a variation associated with historical processes and the spatial configuration of the individual areas. In addition, a different moral economy emerges in each area that favors a certain form of authority and certain bases for the associated mechanisms of domination that reign there. In principle, this may suggest that each area in Rio de Janeiro has its own culture and morals. However, we may suspect that in addition to clearly distinct moral backgrounds, differing circumstances mean that the heterogeneous character of local culture allows for various forms of order to take hold and gain consensus. To put it another way, given the fact that cultures and moralities are not homogeneous and completely coherent entities, but rather contradictory and inconsistent systems, they may provide the basis to legitimize different types of social order, with varying forms of synergy between rational and alternative forms of sovereignty. Thus, this variation also provides an explanation for the different clusters of order emerging between and within civil societies that are part of one state, and that exhibit partially different as well as frequently shifting forms of authority and domination.

\section{Acknowledgments and funding}

We are indebted to the Volkswagen Foundation that granted the funds for the workshop 'Shaping Protected Spaces: The State and Organized Crime in Latin America \& Europe' (from which this special subsection evolved) held at the GIGA Institute of Latin American Studies in Hamburg between September 30 and October 1 2011. We would also like to thank the two anonymous reviewers and particularly Katherine Walker for the careful editing work.

\section{References}

Arias ED (2006) The dynamics of criminal governance: Networks and social order in Rio de Janeiro. Journal of Latin American Studies 38(2): 293-325.

Auyero J and Berti MF (2015) In Harm's Way: The Dynamics of Urban Violence. Princeton, NJ: Princeton University Press.

Barkey K (1994) Bandits and Bureaucrats: The Ottoman Route to State Centralization. Ithaca, NY: Cornell University Press.

Bayart JF, Ellis SDK and Hibou B (1999) The Criminalization of the State in Africa. African Issues series. Bloomington: Indiana University Press.

Becattini G (2004) Industrial Districts: A New Approach to Industrial Change. Cheltenham: Edward Elgar. 
Beckert J and Dewey M (2017) The Architecture of Illegal Markets: Toward an Economic Sociology of Illegality in the Economy. Oxford: Oxford University Press.

Charrad MM and Adams J (2015) Patrimonial Capitalism and Empire. Political Power and Social Theory Vol. 28. Bingley: Emerald Group Publishing.

Clunan AL and Trinkunas HA (2010) Ungoverned Spaces: Alternatives to State Authority in an Era of Softened Sovereignty. Stanford, CA: Stanford Security Studies.

Connell R and Dados N (2014) Where in the world does neoliberalism come from? Theory and Society 43(2): 117-138.

Cribb R (2009) Introduction: Parapolitics, shadow governance and criminal sovereignty. In: Wilson E (ed.) Government of the Shadows: Parapolitics and Criminal Sovereignty. London: Pluto Press.

Davis DE (2010) Irregular armed forces, shifting patterns of commitment, and fragmented sovereignty in the developing world. Theory and Society 39 (3-4): 397-413.

Dewey M (2012) The making of hybrid stateness: Sources of police performance in the conurbano. Revista de Ciencia Política 32(3), 659-672.

Dewey M (2015) El orden clandestino. Política, fuerzas de seguridad y mercados ilegales en Argentina. Buenos Aires: Katz Editores.

Dewey M (2016) Porous borders: The study of illegal markets from a sociological perspective. MPIfG Discussion Paper 16/2.

Erdmann G and Engel U (2007) Neopatrimonialism reconsidered: Critical review and elaboration of an elusive concept. Commonwealth and Comparative Politics 45(1): 95-119.

Erikson E and Parent JM (2007) Central authority and order. Sociological Theory 25(3): 245-267.

Fligstein N (2001) The Architecture of Markets: An Economic Sociology of Twenty-First-Century Capitalist Societies. Princeton, NJ: Princeton University Press.

Fligstein N and MacAdam D (2012) A Theory of Fields. Oxford: Oxford University Press.

Gambetta D (1988) Mafia: The price of distrust. In: Gambetta D (ed.) Trust: Making and Breaking Cooperative Relations. Oxford: Oxford University Press, pp. 158-175.

Gambetta D (1993) The Sicilian Mafia: The Business of Private Protection. Cambridge, MA: Harvard University Press.

Gathmann C and Hillmann H (2014) Commerce and crime: States, property rights, and the war on trade, 1700-1815. Available at: stuff.mit.edu:8001/afs/athena.mit.edu/course/other/ econsocseminar/www/privateers_MIT20062.pdf (accessed 25 July 2015).

Granovetter M (1985) Economic action and social structure: The problem of embeddedness. American Journal of Sociology 91(3): 481-510.

Helmke G and Levitsky S (2006) Informal Institutions and Democracy: Lessons from Latin America. Baltimore: Johns Hopkins University Press.

Hibou B (2004) Privatizing the State. New York: Columbia University Press.

Kupatadze A (2012) Organized Crime, Political Transitions and State Formation in Post-Soviet Eurasia. New York: Palgrave Macmillan.

Lauth HJ (2000) Informal institutions and democracy. Democratization 7(4): 21-50.

Levi M and Stoker L (2000) Political trust and trustworthiness. Annual Review of Political Science 3: 475-507.

Luhmann N (1983) Rechtssoziologie. Wiesbaden: VS Verlag für Sozialwissenschaften.

Nee V (1998) Norms and networks in economic and organizational performance. The American Economic Review 88(2): 85-89.

Nordstrom C (2000) Shadows and sovereigns. Theory, Culture and Society 17(4): 35-54.

North D, Wallis JJ and Weingast B (2009) Violence and Social Orders: A Conceptual Framework for Interpreting Recorded Human History. Cambridge: Cambridge University Press. 
O'Donnell G (1993) On the state, democratization and some conceptual problems: A Latin American view with glances at some postcommunist countries. World Development, Special Issue, 21(8): 1355-1369.

Porter ME (2008) On Competition. Boston: Harvard Business School Press.

Reno W (1995) Corruption and State Politics in Sierra Leone. Cambridge: Cambridge University Press.

Rodgers D (2006) Living in the shadow of death: Gangs, violence and social order in Urban Nicaragua, 1996-2002. Journal of Latin American Studies 38(2): 267-292.

Scott WR (1995) Institutions and Organizations. Thousand Oaks, CA: SAGE.

Swedberg R (2002) The economic sociology of capitalism: Weber and Schumpeter. Journal of Classical Sociology 2(3): 227-255.

Thomson JE (1992) Explaining the regulation of transnational practices: A state-building approach. In: Rosenau JN and Czempiel EO (eds) Governance without Government: Order and Change in World Politics. Cambridge Studies in International Relations 20. Cambridge: Cambridge University Press, pp. 195-218.

Thomson JE (1994) Mercenaries, Pirates, and Sovereigns: State-Building and Extraterritorial Violence in Early Modern Europe. Princeton, NJ: Princeton University Press.

Varese F (2004) The Russian Mafia: Private Protection in a New Market Economy. Oxford: Oxford University Press.

Volkov V (2002) Violent Entrepreneurs: The Use of Force in the Making of Russian Capitalism. Ithaca, NY: Cornell University Press.

Volkov V (2014) The Russian mafia: Rise and extinction. In: Paoli L (ed.) The Oxford Handbook of Organized Crime. Oxford: Oxford University Press, pp. 159-176.

Wacquant LJD (1996) The rise of advanced marginality: Notes on its nature and implications. Acta Sociologica 39(2): 121-139.

Weber M (1956) Wirtschaft und Gesellschaft: Grundriss der verstehenden Soziologie: mit einem Anhang Die Rationalen und soziologischen Grundlagen der Musik, Vol. 2. Tübingen: Mohr.

Weiss L (1987) Explaining the underground economy: State and social structure. The British Journal of Sociology 38(2): 216-234.

Zabludovsky Kuper G (2011) Patrimonialismo y modernización. México: Fondo de Cultura Económica.

Zabludovsky Kuper G (2016) El concepto de patrimonialismo y su aplicación al estudio de México y América Latina. In: Morcillo Laiz À and Weisz E (eds) Max Weber en Iberoamérica. Nuevas interpretaciones, estudios empíricos y recepción. México: Fondo de Cultura Económica, pp. 447-468.

\section{Author biographies}

Matías Dewey is a senior researcher in the project area on the sociology of illegal markets at the Max Planck Institute for the Study of Societies in Cologne, Germany. He studied sociology in Argentina and received his $\mathrm{PhD}$ in Germany. His research is centered on social theory, economic sociology, illegal markets and qualitative research. As a visiting scholar, he has spent time at the University of Oxford, at the MaxPo in Paris and recently at the Department of Sociology at the University of Texas at Austin. He has received grants from the Alexander von Humboldt and Volkswagen foundations. Previous research topics include the market for stolen vehicles in Buenos Aires and Mexico City, and the market for counterfeit clothing in Argentina.

Daniel Míguez holds a degree in sociology from the University of Buenos Aires and a PhD in social anthropology from the Free University of Amsterdam. He is currently a researcher for the National Council for Scientific and Technical Research (CONICET) and a Full Professor of Sociology and 
Anthropology at the School of Human Sciences at the National University of the State of Buenos Aires. He has previously held the positions of head of the Institute for Socio-Historical Studies (2011-2014) at the same university and Director of the Masters Degree in Social and Political Anthropology at the Latin American School of Social Sciences (FLACSO). He has conducted extensive research on urban violence, especially on issues of organized crime, juvenile delinquency and school conflicts among the urban poor, publishing more than 70 articles and 10 books on these topics.

Marcelo Fabián Sain is a professor and researcher at the Department of Social Sciences at the Universidad Nacional de Quilmes, Argentina. He holds a degree in political science and a $\mathrm{PhD}$ in social sciences from the University of Campinas (São Paulo, Brazil). He is also Director of the Núcleo de Estudios de Gobierno y Seguridad at the Universidad Metropolitana para la Educación y el Trabajo, Buenos Aries. He has conducted research on police institutions and on military-civic relations. He has extensively published on policing and public safety, organized crime, military issues, political science and international security. He has written several books and numerous academic papers.

\section{Résumé}

Relativisant les théories dualistes qui considèrent l'ordre social comme un produit des États puissants et non des États faibles, cet article élabore un cadre conceptuel visant à interpréter les ordres sociaux hybrides institués par des acteurs judiciaires et extrajudiciaires. II pose comme hypothèse initiale que les formes hybrides de domination sociale, résultant de l'interaction entre les acteurs judiciaires et extrajudiciaires et régulées par la combinaison de règles bureaucratiques rationnelles et de pratiques néopatrimoniales, peuvent générer des retombées économiques et politiques positives, notamment en matière de création d'emploi, de fourniture de services de base et d'exercice de l'autorité. Dans des contextes de crises économiques durables, de ségrégation ethnique, de marginalisation sociale et d'inégalités persistantes, ces incidences permettent de définir un ordre qui réduit les incertitudes et régule les attentes sociales. À cet égard, les marchés illicites qui sont socialement tolérés jouent un rôle décisif dans ce domaine. Confirmé par une recherche récente et novatrice figurant dans le présent article, ce travail conclut en suggérant des pistes de recherche future.

\section{Mots-clés}

Ordre social, marchés illicites, État, informalité, légitimité, agrégat, ordre social hybride, patrimonialisme

\section{Resumen}

Al alejarse desde perspectivas dualistas que ven el orden social como el producto de Estados fuertes, pero no de estados débiles, en este artículo se desarrolla un marco conceptual para la interpretación de los órdenes sociales híbridos, es decir, las establecidas tanto por actores legales como extralegales. La premisa inicial es que las formas híbridas de dominación social que resulta de la interacción entre los actores legales y extra-legales, y regulada por una combinación de reglas burocráticas racionales 
y neo-patrimoniales, produce resultados económicos y políticos relevantes, tales como la creación de empleo, el suministro de los servicios básicos y la producción de la autoridad. Especialmente en contextos de crisis económica continua, de segregación étnica, marginación social y desigualdad persistente, estos resultados tienen efectos de ordenamiento tanto en términos de reducción de la incertidumbre cuanto en la regulación de las expectativas sociales. Además, en tales contextos sociales, los mercados ilegales socialmente tolerados juegan un papel decisivo. Con el apoyo de la investigación reciente e innovador incluidos en esta Subsección Especial, el artículo concluye con la hipótesis destinadas a promover futuras investigaciones.

\section{Palabras clave}

Orden social, mercados ilegales, estado, informalidad, legitimidad, agrupación, orden social híbrido, patrimonialismo 